\title{
PENGARUH PEMBERIAN HORMON IGF-I (INSULIN-LIKE GROWTH FACTOR-I) RECOMBINANT MOUSE TERHADAP PERTUMBUHAN IKAN GURAME (OSPHRONEMUS GOURAMY)
}

\section{Effect of hormones Recombinant Mouse IGF-I (Insulin-Like Growthfactor-I) on The Growth of Osphronemus gouramy}

\author{
Dimas Eraparamarta Harkitiyanto ${ }^{1^{*}}$, Woro Hastuti Satyantini ${ }^{2}$,dan Prayogo ${ }^{2}$ \\ ${ }^{1}$ Mahasiswa Program Studi Budidaya Perairan Fakultas Perikanan dan Kelautan Universitas Airlangga, Surabaya \\ 60115 \\ ${ }^{2}$ Departemen Manajemen Kesehatan Ikan dan Budidaya PerairanFakultas Perikanan dan Kelautan Universitas \\ Airlangga, Surabaya 60115
}

\begin{abstract}
Abstrak
Konsumsi ikan gurame semakin meningkat setiap tahun mengakibatkan tingginya jumlah permintaan, belum dapat diimbangi produksi yang mencukupi. Laju pertumbuhan ikan gurame dikenal lambat, sehingga untuk mencapai ukuran konsumsi diperlukan waktu pemeliharaan relatif lama. Peningkatan kualitas produksi dengan meningkatkan kemampuan metabolisme sel terhadap asupan pakan ikan melalui penyuntikan hormon insulin-like growth factor-I(IGF-I) diharapkan dapat memacu pertumbuhan, dan produksi ikan dapat ditingkatkan. Tujuan dari penelitian ini adalahuntuk mengetahui pengaruh pemberian hormon (IGF-I) recombinant mouse terhadap peningkatan pertumbuhan ikan gurame(Osphronemus gouramy). Penelitian adalah metode eksperimental rancangan acak lengkap (RAL), menggunakan ikan gurame sebanyak 80 ekor yang terbagi dalam 4 perlakuanP0 : tanpa disuntik hormon IGF-I, P1 : disuntik hormon IGF-I dengan dosis $10 \mathrm{ng} / \mathrm{ml}, \mathrm{P} 2$ : disuntik hormon dengan dosis $20 \mathrm{ng} / \mathrm{ml}$ dan P3 : disuntik hormon dengan dosis $40 \mathrm{ng} / \mathrm{ml}$ masing-masing 5 ulangan setiap ulangan 4 ekor ikan gurame. Perlakuan dengan injeksi hormon IGF-I recombinant mouse. Parameter yang diukur adalah pertumbuhan. Hasil penelitian menunjukkan bahwa perlakuan penyuntikan hormon IGF-I recombinant mouse dengan dosis yang berbeda memberikan perbedaan yang nyata $(\mathrm{p}<0,05)$; pertumbuhan berat $(\mathrm{P} 0: 0 \mathrm{ng} / \mathrm{ml}=7,23$ gram \pm 0,37 gram dan $\mathrm{P} 3: 40 \mathrm{ng} / \mathrm{ml}=26,35$ gram $\pm 1,89$ gram $)$ ;pertumbuhan panjang ( $\mathrm{P} 0: 0 \mathrm{ng} / \mathrm{ml}=5,76 \mathrm{~cm} \pm 0,38 \mathrm{~cm}$ dan $\mathrm{P} 3: 40 \mathrm{ng} / \mathrm{ml}=7,93 \mathrm{~cm} \pm 0,07 \mathrm{~cm})$.). Kesimpulan penelitian bahwa IGF-I recombinant mouse berpengaruh meningkatkan pertumbuhan pada peningkatan berat dan panjang ikan gurame pada perlakuan penyuntikan $40 \mathrm{ng} / \mathrm{ml}$.
\end{abstract}

Kata kunci: Ikan gurame(Osphronemus gouramy), insulin-like growth factor-I (IGF-I), pertumbuhan

\begin{abstract}
Osphronemus gouramy consumption is increasing every year which causes in a high number of inquiries for this fish, cannot be offset sufficiently by the amount of production. The growth rate of $O$. gouramy are known relatively slow, so that to achieve the required consumption is relatively long. Quality improvement of productivity by improving the ability of cell metabolism to intake of fish feed through hormone injection recombinant mouse insulin-like growth factor-I (IGF-I) is expected to spur growth, so that fish production can be increased. The aim of this study is to determine the effect of the hormone IGF-I recombinant mouse to the increased growth of O.gouramy. The benefits of this research are expected to deliver the benefitsof science in the form of scientific information to the public in general and fish farmers especially about the effect of the hormone recombinant mouse IGF-I on the growth of $O$. gouramy. The research is methodis carried out experimentally by using completely randomized design (CRD), this study uses 80 O. gouramy were divided into 4 treatment $\mathrm{P} 0$ : without hormone injectionsof IGF-I, P1: injected with the hormone IGF-I at a dose of $10 \mathrm{ng} / \mathrm{ml}, \mathrm{P} 2$ : injected with the hormone IGF-I at a dose of $20 \mathrm{ng} / \mathrm{ml}$ and P3: injected with the hormone ata dose of $40 \mathrm{ng} / \mathrm{ml}$ each of 5 replicates each test $4 \mathrm{O}$. gouramy. The hormone IGF-I recombinant mouse is done by injection. The treatment with hormone injection of recombinant mouse IGF-I. Parameters measured were growth. The results showed that the treatment hormone injection of recombinant mouse IGF-I with different doses gave significant differences ( $\mathrm{p}$ $<0.05$ ); weight growth (P0: $0 \mathrm{ng} / \mathrm{ml}=7,23$ gram $\pm 0,37$ gram dan P3: $40 \mathrm{ng} / \mathrm{ml}=26,35$ gram $\pm 1,89$ gram.); length growth $(\mathrm{P} 0: 0 \mathrm{ng} / \mathrm{ml}=5,76 \mathrm{~cm} \pm 0,38 \mathrm{~cm}$ dan $\mathrm{P} 3: 40 \mathrm{ng} / \mathrm{ml}=7,93 \mathrm{~cm} \pm 0,07 \mathrm{~cm})$. The conclusion that recombinant mouse IGF-Iincreased the growth by increasing in weight and length of O. gouramy and improvement of the growth occurred in the treatment injection of the dose: $40 \mathrm{ng} / \mathrm{ml}$.
\end{abstract}

Keywords : Growth, insulin-like growth factor-I (IGF-I), O.gouramy 


\section{Pendahuluan}

Ikan gurame (Osphronemus gouramy) adalah ikan konsumsi air tawar yang telah lama dikenal di Indonesia dan cukup banyak peminatnya. Cita rasanya yang gurih, tekstur dagingnya tidak lembek menjadikan ikan gurame sangat digemari oleh masyarakat Indonesia, khususnya masyarakat pulau Jawa (Arfah dan Carman, 2006). Ikan guramejuga dikenal sebagai ikan budidaya air tawar dengan pertumbuhanyang lambat. Kementerian Kelautan dan Perikanan (KKP) menetapkan kebijakan serta melaksanakan beberapa program berupa kegiatan pembangunan yang disesuaikan dengan perubahan yang terjadi pada lingkungan nasional maupun internasional. Pemenuhan kebutuhan ekonomi masyarakat yang berfokus pada kesejahteraan rakyat diperlukan suatu usaha yakni salah satunya berupa peningkatan produktivitas budidaya perikanan. Kurun waktu tahun 2014-2015 di pasar Provinsi Jawa Timur mengalami peningkatan produksi ikan dari 8.425 menjadi 9.525 ton, tetapi hanya membutuhkan pasokan ikan gurame sebesar 12-13 ton per minggu untuk pasar lokal dan sisa hasil produksi didistribusikan keseluruh Indonesia. Provinsi Jawa Timur merupakan sentral penghasil ikan gurame penyumbang $60-70 \%$ total produksi di Indonesia. Secara nasional kebutuhan ikan gurame masih kurang (Pusat Data Statistik dan Informasi KKP, 2015).

Konsumsi ikan gurame yang meningkat setiap tahun mengakibatkan tingginya jumlah permintaan, keadaan ini belum dapat diimbangi dengan jumlah produksi yang cukup. Laju pertumbuhan ikan gurame dikenal relatif lambat, untuk mencapai ukuran konsumsi diperlukan waktu pemeliharaan relatif cukup lama.Upaya untuk peningkatan produksi ikan diterapkan dengan berbagai usaha, misalnya pemilihan bibit yang baik melalui peningkatan kualitas produksi (Mulyati dkk., 2002; Sakdiah dkk., 2003), perbaikan pakan (Djarijah,1995; Suprayudi dan Setiawati. 2003), dan penerapan teknologi budidaya pemeliharaan ikan (Arfah dan Carman, 2006). Peningkatan kualitas produktivitas dengan cara meningkatkan kemampuan metabolisme sel terhadap asupan bahan pakan ikan melalui pemberian hormon insuline-like growth factor-I diharapkan dapat memacu pertumbuhan, sehingga jumlah produksi ikan dapat ditingkatkan (Poppinga et al., 2007; Maggio et al., 2013).

Insuline-like growth factor-I (IGF-I) atau somatomedin adalah polipeptida 
growth factor yang disekresikan oleh hati dan berbagai jaringan sebagai respons dari rangsangan growth hormone (GH). IGF-I adalah mediator untuk rangsangan dari hormon pertumbuhan (growth hormone) (Hafez et al., 2000). Hormon pertumbuhan merangsang produksi IGF-I di hati (Bjornsson et al., 2004), yang berperan penting dalam mengatur beberapa proses fisiologi seperti pertumbuhan, metabolisme, perkembangan (Pozios et al., 2001), reproduksi (Weber and Sullivan, 2000), dan osmoregulasi (McCormick, 2001). Insulin dan insulin-like growth factor I (IGF-I) strukturalnya berhubungan dekat dengan peptida dan terkait dengan keluarga utama insulin, dengan fungsi biologis binding (mengikat) reseptor permukaan sel tertentu. Insulin terikat dalam hati, otot putih dan jantung, pada otak atau organ reproduksi telah dipelajari pada spesies ikan yang berbeda (Gutiérrezet al., 1995; Leibush, et al., 1996). Fungsi utama IGF-I merangsang pertumbuhan dan diferensiasi (Le Roith et al., 1995). Insulin dan IGF-I erat berinteraksi dalam regulasi metabolisme dan pertumbuhan. Pada mamalia, IGF-I mempengaruhi baik penyerapan dan metabolisme glukosa (Dohm et al., 1990; Boulware et al., 1992) dan sintesis protein dalam otot rangka
(Fuller et al., 1992). IGF-I adalah bersifat hipoglikemik pada ikan (Plisetskaya et al., 1994).

Saat ini penelitian mengenai insulinlike growth factor-I jarang dilakukan pada ikan terutama di Indonesia, sedangkan penerapan IGF-I untuk tujuan peningkatan pertumbuhan pada ikan di Indonesia belum pernah dilakukan. Tujuan dari penelitian untuk mengetahui pengaruh pemberian hormon IGF-I recombinant mouse pada peningkatan pertumbuhan ikan gurame (Osphronemus gouramy).

\section{Materi dan Metode}

\section{Bahan dan Alat Penelitian}

Bahan penelitian: ikan gurame ukuran panjang awal 10-15 $\mathrm{cm}$ dan berat awal 150-200 gram sebanyak 80 ekor, pengisi akuarium menggunakan air sumur, pakan ikan buatan pabrik, hormon IGF-I (recombinant mouse,Cat\#591406, Biolegend, San Diego USA) dan adjuvant. Peralatan penelitian: akuarium kaca sebanyak 4 buah dengan dimensi ukuran $150 \mathrm{~cm}$ x $50 \mathrm{~cm}$ x $50 \mathrm{~cm}$, masingmasing akuarium di sekat dengan kaca menjadi 5 bagian, sehingga masingmasing bagian berukuran $30 \mathrm{~cm}$ x $50 \mathrm{~cm} \times$ $50 \mathrm{~cm}$ dengan kelengkapannya seperti aerator, selang aerasi dan penutup kawat ram diatas akuarium, alat suntik (syringe) 
tuberculine disposable $1 \mathrm{ml}$, sarung tangan karet (rubber glove), alat ukur panjang satuan sentimeter $(\mathrm{cm})$ atau penggaris, timbangan analitik satuan gram.

\section{Rancangan Penelitian}

Penelitian dilakukan secara eksperimental menggunakan rancangan acak lengkap (RAL). Ikan gurame sebanyak 80 ekor, dibagi acak pada akuarium 1 disekat menjadi 5 bagian, per sekat diisi 4 ekor sebagai kontrol (P0),pada akuarium 2,3, dan 4 sama dengan akuarium 1. Tiap sekat akuarium berisi 4ekor sebagai perlakuan (P1, P2, P3). Setiap perlakuan diulang sebanyak 5 ulanganPemberian hormon IGF-Imelalui injeksi per im yaitu:

P0 : Ikan gurame disuntik $\mathrm{NaCl}$ fisiologis $0,1 \mathrm{ml}$ per $\mathrm{im}$. setiap ikan disuntik satu kali.

P1 : Ikan gurame disuntik hormon IGF-Irecombinant mouse $0,1 \mathrm{ml}$ per im. dalam larutan $\mathrm{NaCl}$ fisiologis (dosis $10 \mathrm{ng} / \mathrm{ml}$ ) setiap ikan satu kali.

P2 : Ikan gurame disuntik hormon IGF-I recombinant mouse $0,1 \mathrm{ml}$ (per im) dalam larutan $\mathrm{NaCl}$ fisiologis (dosis $20 \mathrm{ng} / \mathrm{ml}$ ) setiap ikan satu kali.

P3 : Ikan gurame disuntik hormon
IGF-Irecombinant mouse $0,1 \mathrm{ml}$ (per im) dalam larutan $\mathrm{NaCl}$ fisiologis(dosis $40 \mathrm{ng} / \mathrm{ml}$ ) setiap ikan satu kali.

\section{Persiapan Wadah dan Ikan Gurame}

Wadah pemeliharaan menggunakan akuarium kaca sebanyak 4 buah yang sudah dibagi menjadi 20 bagian/sekat dengan ukuran dimensi : panjang $\mathrm{x}$ lebar $\mathrm{x}$ tinggi adalah $30 \mathrm{~cm} \times 50 \mathrm{~cm} \times 50 \mathrm{~cm}$, diisi air sebanyak $3 / 4$ dari volume akuarium sebanyak 56,25 $\ell$ air sumur dan didiamkan selama semalam.

Ikan gurame sebanyak 80 ekor dibagikan secara acak ke dalam 20 bagian/sekat dengan masing-masing sekat/bagian diisikan 4 ekor ikan gurame. Ikan gurame dalam akuarium diadaptasi selama 7 hari untuk menghindari stress dengan kondisi lingkungan suhu, pakan dan suasana tempat yang baru. Setelah diadaptasi ikan gurame ditimbang dan diukur panjang dan berat badan pada awalnya,selanjutnyadiberikan perlakuan suntikanhormon IGF-I dengan dosis yang sesuai pada masing-masing kelompok kontrol dan kelompok perlakuan.

\section{Pemberian Pakan}

Pakan ikan gurame yang diberikan selama masa penelitian menggunakan pakan buatan pabrik pakan ikan, diberikan terbagi dalam tiga kali sehari yaitu pada 
waktu pagi jam 06.00, siang jam 13.00, dan malam jam 20.00. Pemberian pakan disesuaikan berdasarkan berat badan ikan yaitu 3\% berat badan ikan. Pakan berupa butiran (pellet) yang dijual di pasaran khusus untuk ikan.

\section{Penyuntikan Hormon IGF-I}

Hormon IGF-I recombinant mouse diencerkan dengan memasukkan adjuvant pelarutnya sebanyak $0,9 \mathrm{ml}$, diencerkan lagi sesuai dengan dosis yang diberikan pada perlakuan yaitu; $10 \mathrm{ng}, 20 \mathrm{ng}$ dan 40 ng, diberikan melalui suntikan menggunakan syringe injeksi $1 \mathrm{ml}$ pada bagian otot daging punggung ikan dengan arah suntikan dari belakang ke depan dengan dosis yang sesuai dengan perlakuan sebanyak 0,1 ml. Dosis IGF-I yang diberikan sesuai dengan saran Reinecke (2010) dari ulasan berbagai penelitian IGF-I pada ikan.

\section{Pengukuran Parameter}

Parameter yang diukur adalah pertumbuhan. Pertumbuhan berat mutlak dan pertumbuhan panjang mutlak sebagai data pertumbuhan ikan diukur pada awal penelitian dan akhir penelitian. Penelitian dilakukan selama 60 hari. Penghitungan pertumbuhan ikan gurame (Osphronemus gouramy) dilakukan pada awal penelitian sampai akhir penelitian. Penghitungan pertumbuhan berat mutlak dan per-tumbuhan panjang mutlak menggunakan rumus yang dikemukakan oleh Zonneveld et al (1991), sebagai berikut :

\section{Pertumbuhan Berat Mutlak dan} Panjang Mutlak

Pertumbuhan berat mutlak (G) dihitung dengan rumus $\mathrm{G}=\mathrm{Wt}-\mathrm{Wo}$

G : Pertumbuhan berat mutlak (gram),

Wt : Berat tubuh ikan pada akhir penelitian (gram/ekor),

Wo : Berat tubuh ikan pada awal penelitian (gram/ekor).

Pertumbuhan panjang mutlak (L)dihitung dengan rumus $\mathrm{L}=\mathrm{Lt}-\mathrm{Lo}$

L : Pertumbuhan panjang mutlak $(\mathrm{cm})$,

Lt : Panjang tubuh ikan pada akhir penelitian (cm/ekor),

Lo : Panjang tubuh ikan pada awal penelitian ( $\mathrm{cm} / \mathrm{ekor})$.

\section{Analisis Data}

Data yang diperoleh berupa ukuran berat dan panjang badan ikan gurame ditabulasikan dalam bentuk tabel, selanjutnya dianalisis menggunakan Anova untuk mengetahui pengaruh IGF-I dari masing-masing perlakuan. Untuk melihat perbedaan antar perlakuan maka dilanjutkan dengan Tuckey. Pengolahan data statistik menggunakan fasilitas program: IBM SPSS Statistics Version 20. 


\section{Hasil Penelitian}

Hasil penelitian pertumbuhan berat dan panjang badan ikan gurame (Osphronemus gouramy) disajikan pada Tabel 1 dan Tabel 2. Hasil analisis statistik menggunakan Anova satu arah (one way anova) antara perlakuan $\mathrm{P} 0$ : IGF-I dosis $0 \mathrm{ng} / \mathrm{ml}$ dengan P1: IGF-I recombinant mouse dosis $10 \mathrm{ng} / \mathrm{ml}$ peningkatan berat ikan gurame (Osphronemus gouramy) (Tabel 1).

Hasil analisis statistik menggunakan Anova satu arah (oneway anova) antara perlakuan P0: IGF-I dosis $0 \mathrm{ng} / \mathrm{ml}$ dengan P1: IGF-I recombinant mouse dosis 10 $\mathrm{ng} / \mathrm{ml}$ menunjukkan tidak berbeda nyata $(\mathrm{p}>0,05)$, P1: IGF-I recombinant mouse dosis $10 \mathrm{ng} / \mathrm{ml}$ dan P2: IGF-I

Tabel 1. Pertumbuhan berat ikan gurame pada perlakuan dengan penyuntikan hormon IGF-I recombinant mouse

\begin{tabular}{|c|c|c|}
\hline Perlakuan & $\mathrm{N}$ & $\begin{array}{l}\text { Pertumbuhan berat }(\mathrm{G}) \\
\text { Rata-rata } \pm \text { SD (gram) }\end{array}$ \\
\hline P0 (Kontrol) & 5 & $7,23 \pm 0,37^{\mathrm{a}}$ \\
\hline $\mathrm{P} 1: 10 \mathrm{ng} / \mathrm{ml}$ & 5 & $17,01 \pm 0,42^{b}$ \\
\hline $\mathrm{P} 2: 20 \mathrm{ng} / \mathrm{ml}$ & 5 & $18,22 \pm 0,35^{b}$ \\
\hline P3: $40 \mathrm{ng} / \mathrm{ml}$ & 5 & $26,35 \pm 1,89^{c}$ \\
\hline
\end{tabular}

Keterangan: tanda superskrip yang berbeda menunjukkan perbedaan nyata $(p<0,05)$

Tabel 2. Pertumbuhan panjang ikan gurame pada perlakuan dengan penyuntikan hormon IGF-I recombinant mouse

\begin{tabular}{|c|c|c|}
\hline Perlakuan & $\mathrm{N}$ & $\begin{array}{l}\text { Pertumbuhan panjang }(\mathrm{L}) \\
\text { Rata-rata } \pm \mathrm{SD}(\mathrm{cm})\end{array}$ \\
\hline P0 (Kontrol) & 5 & $5,76 \pm 0,38^{\mathrm{a}}$ \\
\hline $\mathrm{P} 1: 10 \mathrm{ng} / \mathrm{ml}$ & 5 & $5,88 \pm 0,17^{\mathrm{a}}$ \\
\hline $\mathrm{P} 2: 20 \mathrm{ng} / \mathrm{ml}$ & 5 & $6,42 \pm 0,08^{b}$ \\
\hline P3: $40 \mathrm{ng} / \mathrm{ml}$ & 5 & $7,93 \pm 0,07^{\mathrm{c}}$ \\
\hline
\end{tabular}

Keterangan: tanda superskrip yang berbeda menunjukkan perbedaan nyata $(p<0,05)$

berbeda nyata $(\mathrm{p}<0,05), \quad \mathrm{P} 1$ : IGF-I recombinant mouse dosis $20 \mathrm{ng} / \mathrm{ml}$ recombinant mouse dosis $10 \mathrm{ng} / \mathrm{ml}$ dan P2: IGF-I recombinant mouse dosis 20 $\mathrm{ng} / \mathrm{ml}$ tidak berbeda nyata $(\mathrm{p}>0,05), \mathrm{P} 2$ : IGF-I recombinant mouse dosis $20 \mathrm{ng} / \mathrm{ml}$ dan P3: IGF-I recombinant mouse dosis $40 \mathrm{ng} / \mathrm{ml}$ berbeda nyata $(\mathrm{p}<0,05)$, pada menunjukkan berbeda nyata $(\mathrm{p}<0,05), \mathrm{P} 2$ : IGF-I recombinant mouse dosis $20 \mathrm{ng} / \mathrm{ml}$ dan P3: IGF-I recombinant mouse dosis $40 \mathrm{ng} / \mathrm{ml}$ menunjukkan berbeda nyata $(\mathrm{p}<0,05)$, pada per-tumbuhan panjang ikan gurame (Osphronemus gouramy) (Tabel 2). 


\section{Pembahasan}

Axis (poros) hormon pertumbuhan (growth hormonedan insulin-like growth factor (GH-IGF) menimbulkan efek dalam pengaturan pertumbuhan somatik dan metabolisme pada ikan teleost. Axis (poros) GH-IGF dimulai di kelenjar hipofisis anterior di bawah kontrol/kendali beberapa hormon hipotalamus, termasuk growth hormone releasing hormone (GHRH) (Vong et al., 2003; Peterson et al., 2005). Insulin-like growth factor binding protein (IGFBP) memainkan peranan sentral dalam memperpanjang paruh hidup (half-live) IGF yang mengkoordinasi dan mentransportkan IGF pada sirkulasi (Moriyama et al., 2000). Keluarga IGFBP ini cakupannya diperluas termasuk IGFBP related protein (IGFBPrP) yang juga berperanan dalam mengatur aktivitas IGF (Rodgers et al., 2008). IGF membangkitkan respons biologisnya melalui reseptor pada jaringan target menghasilkan peningkatan pertumbuhan (Peterson et al., 2009). Konsentrasi serum IGF-I menstimulasi atau menekan pengeluaran GH dari hipofisis anterior melalui umpan balik pada mamalia dan vertebrata yang lebih rendah, seperti yang telah ditunjukkan terutama dalam ikan bertulang (bony fish). Pada mamalia maupun ikan bony fish, poros $\mathrm{GH}$ hipofisis/ IGF-I hati terlibat dalam regulasi endokrin pada proses fisiologis penting tampaknya ada (Eppler, 2011).

Pada ikan seperti pada vertebrata lainnya, ingesti dan akumulasi energi adalah kunci untuk kelangsungan hidup, pertumbuhan dan reproduksi, dengan lemak tubuh normal sebagai cadangan energi yang penting. Hormon pertumbuhan $(\mathrm{GH})$ menampilkan pluripotensi yang mencakup berbagai macam efek terpisah dari aksi stimulasi pertumbuhan baik pada mamalia maupun ikan. Namun kebanyakan dari aksi GH selanjutnya bertindak melalui produksi dan stimulasi dari pengeluaran insulin-like growth factor-I (IGF-I) (Kling et al., 2011).

Insulin-like growth factor-I secara struktural dan fungsional berhubungan dengan insulin dan aksi/tindakan biologisnya pada ikan meliputi regulasi pertumbuhan, stimulasi diferensiasi jaringan, reproduksi dan osmoregulasi (Duan, 1998). IGF-I lebih efektif daripada insulin dalam merangsang penyerapan glukosa dan asam amino sel-sel otot pada ikan rainbow trout (Oncorhynchus mykiss), menunjukkan bahwa hormon ini juga terlibat dalam regulasi metabolisme karbohidrat dan bahkan bisa melebihi relevansinya dari insulin (Enes, 2011). 
Insulin-like growth factor-Iadalah salah satu anggota penting dalam IGF signaling, dan terlibat dalam pengaturan pertumbuhan dan perkembangan otot rangka pada vertebrata (Duan et al., 2010). Sebagai contoh, berat (massa) tubuh lahir dengan IGF-1 atau IGF-2 pada tikus knockout adalah sekitar 60\% lebih berat dari pada jenis tikus liar (Liu et al., 1993). Pemberian berlebih dari IGF-I pada tikus meningkatkan massa tubuh sebesar 30\% (Mathews et al., 1988). Pada kebanyakan spesies ikan, IGF-I pada sirkulasi darah atau jaringan IGF-I tingkat mRNA positif berkorelasi dengan ransum makanan, kandungan protein dan kecepatan pertumbuhan (Carnevali et al., 2006;. Beckman et al., 2004). Penyuntikan IGF-I implan memberikan kontribusi untuk mempercepat pertumbuhan ikan (McCormick et al., 1992), seperti yang dirangkum oleh Yanet al., (2012). Pada banyak spesies ikan, kadar IGF-I sirkulasi darah atau jaringan dari mRNA berkorelasi positif dengan ransum makanan, kandungan protein diet, dan kecepatan pertumbuhan badan (Beckman et al., 2004). Pada vertebrata, sistem IGF sangat penting dalam pembentukan dan pemeliharaan otot rangka (Le Roith et al., 2001; Stewart dan Rotwein, 1996; Benito et al., 1996) karena bertindak sebagai tombol ampuh positif untuk mengatur pertumbuhan otot (Florini et al., 1996; Le Roith et al., 2001), yang dikutip oleh Montserrat et al., (2007).

Insulin-like growth factor-I dalam sirkulasi diusulkan sebagai indeks yang dapat diandalkan (reliable) untuk pertumbuhan ikan baru-baru ini terkait dengan tingkat pertumbuhan individu dalam kondisi gizi yang berbeda dan/ atau yang berubah (Beckman et al., 2004 Picha et al., 2008 ${ }^{\text {; }}$ Beckman, 2011). Biasanya, tingkat sirkulasi IGF-I yang menurun saat ikan dibatasi jatah pakannya atau tidak diberi pakan, dan dikembalikan pakannya dengan meningkatkan ransum pakan atau diberikan pakan kembali (Picha et al., 2008 ;. Beckman, 2011). Tingkat serum IGF-I pada ikan masu salmon berumur setahun menunjukkan pola serupa dengan ikan jenis lain, yaitu ada korelasi positif antara kadar serum IGF-I dan tingkat pertumbuhan individu (growth rate) baik panjang dan berat ikan, yang mendukung gagasan bahwa sirkulasi IGF-I merupakan indeks pertumbuhan yang baik pada berbagai spesies ikan, yang dirangkum dari beberapa peneliti oleh Kawaguchi et al., (2013) dalam penelitiannya. 


\section{Kesimpulan dan Saran}

Pemberian hormon insulin-like growth factor-I (IGF-I) melalui injeksi dapat meningkatkan pertumbuhan berat dan panjang ikan gurame.Dosis terbaik untuk meningkatkan pertumbuhan berat dan panjang adalah $40 \mathrm{ng} / \mathrm{ml}$. Penyuntikan hormon IGF-I dapat meningkatkan pertumbuhan berat dan panjangpada ikan gurame dapat diberikan hormon IGF-I dengan dosis $40 \mathrm{ng} / \mathrm{ml}$.

\section{Daftar Pustaka}

Arfah, L. M. dan O. Carman. 2006. Pemijahan Secara Buatan pada Ikan Gurame Osphronemus Gouramy Lac. dengan Penyuntikan Ovaprim. Jurnal Akuakultur Indonesia, 5 (2) : 103112.

Beckman, B.R., M. Shimizu, B.A.Gadberry, and K.A. Cooper. 2004. Response of The Somatotropic Axis of Juvenile Coho Salmon to Alterations in Plane of Nutrition with An Analysis of The Relationships Among Growth Rate and Circulating IGF-I and $41 \mathrm{kDa}$ IGFBP. Gen. Comp. Endocrinol. 135: 334-344.

Björnsson B.Th., Johansson, V., Benedet, S., Einarsdottir, I.E., Hildahl, J., Agustsson, T., Jönsson, E., 2004. Growth hormone endocrinology of salmonids: regulatory mechanisms and mode of action. Fish Physiol. Biochem. In: Plisetskaya, E.M. (Ed.), Special Issue: Fish Growth and Metabolism. Environmental,
Nutritional and Hormonal regulation. 27: 227-242.

Boulware, S.D., W.V. Tamborlane, L.S. Matthews, and R.S. Sherwin. 1992. Diverse Effects of InsulinLike Growth Factor 1 on Glucose, Lipid and Amino Acid Metabolism. Am. J. Physiol 262: 130-E133.

Carnevali, O., L. de Vivo,R. Sulpizio, G. Gioacchini,I. Olivotto, S.Silvi, and A. Cresci. 2006. Growth improvement by probiotic in European sea bass juveniles (Dicentrarchus labrax, L.), with particular attention to IGF-1, myostatin and cortisol gene expression. Aquaculture 258:430438.

Djarijah, A. S. 1995. Pakan Ikan Alami. Kanisius. Yogyakarta.

Dohm, G.H., C.W. Elton, M.S. Raju, N.D. Mooney, R. Dimarchi, W.J. Pories, E.G. Flickinger, S.M. Atkinson, Jr., and J.F. Caro. 1990. IGF-1 Stimulated Glucose Transport in Human Skeletal Muscle and IGF-1 Resistance in Obesity and NIDDM, Diabetes. 39: 10281032.

Duan, C., H. Ren, and S. Gao, S. 2010. Insulin-Like Growth Factors (IGFs), IGF Receptors, and IGFBinding Proteins: Roles in Skeletal Muscle Growth and Differentiation. Gen. Comp. Endocrinol. 167:344-351.

Enes, P., H. Peres, J. Sanchez-Gurmaches, I. Navarro, J. Gutiérrez, A. OlivaTeles. 2011. Insulin and IGF-I response to a glucose load in European sea bass (Dicentrarchus labrax) juveniles. Aquaculture. 315: 321-326. 
Eppler, E. 2011. The Insulin-Like Growth Factor I (IGF-I) Within the Bony Fish Pituitary: New Morphofunctional and Phylogenetic Aspects. The Open Neuroendocrinology Journal. 4: 43-50.

Fuller, S.J., J.R. Mynett, and P.H. Sugden. 1992. Stimulation of Cardiac Protein Synthesis by Insulin-Like Growth Factors. Biochem. J. 282: 85-90.

Gutiérrez, J., M. Párrizas, M.A. Maestro, I. Navarro, and E.M. Plisetskaya. 1995. Insulin and IGF-I Binding and Tyrosine Kinase Activity in Fish Heart, J. Endocrinol. 146: $35-44$.

Hafez, ESE., Jainudeen, MR., and Rosnina, Y. 2000. Chapter 3 : Hormones, Growth Factors, and Reproduction. In : Reproduction in Farm Animals. Edited by : Hafez and Hafez. $7^{\text {th }}$ Ed. Lippincott Williams \& Wilkins. Philadelphia, New York, Tokyo. P. 35-54.

Kawaguchi, K., N. Kaneko, M. Fukuda, Y. Nakano, S. Kimura, A. Hara, and M. Shimizu. 2013. Responses of insulin-like growth factor (IGF)-I and two IGF-binding protein-1 subtypes to fasting and re-feeding, and their relationships with individual growth rates in yearling masu salmon (Oncorhynchus masou). Faculty of Fisheries Sciences, Hokkaido University, 3-1-1 Minato, Hakodate, Hokkaido 11 041-8611, Japan.

Kling, P., Jönsson, E., Nilsen, T.O., Einarsdottir, I.E., Rønnestad, I., Stefansson, S.O., Björnsson, B.T. 2011. The role of growth hormone in growth, lipid homeostasis, energy utilization and partitioning in rainbow trout: Interactions with leptin, ghrelin and insulin-like growth factor I. General and Comparative Endocrinology 175 (2012): 153-162.

Leibush, B., M. Párrizas, I. Navarro, Y. Lappova, M.A. Maestro, M. Encinas, E.M. Plisetskaya, and J. Gutiérrez. 1996. Insulin and Insulin-Like Growth Factor-I Receptors in Fish Brain. Regul. Peptides. 61: 155-161.

Le Roith, D., M. Adamo, H. Werner, and C.T. Roberts, Jr. 1995. Molecular and Cellular Biology of The Insulin-Like Growth Factors. In: B.D. Weintraub (Ed.), Molecular Endocrinology: Basic Concepts and Clinical Correlations, Raven Press, New York. pp. 181-193.

Liu, J. P., Baker, J., Perkins, A. S., Robertson, E. J. and Efstratiadis, A. 1993. Mice carrying null mutations of the genes encoding insulin-like growth factor I (Igf-1) and type 1 IGF receptor (Igf1r). Cell. 75: 59-72.

Maggio, M., F. De Vita, F. Lauretani, V. Buttò, G. Bondi, C. Cattabiani, A. Nouvenne, T. Meschi, E Dall'Aglio, and G.P. Ceda. 2013. Review IGF-1, The Cross Road of The Nutritional, Inflammatory and Hormonal Pathways to Frailty. Nutrients 5: 4184-4205.

Mathews, L.S., R.E. Hammer, R.R. Behringer,A.J. D'Ercole, G.I. Bell,R.L. Brinster, and R.D. Palmiter. $1988 . \quad$ Growth Enhancement of Transgenic Mice Expressing Human Insulin-Like Growth Factor I. Endocrinology. 123:2827-2833.

McCormick, S.D. 2001. Endocrine Control of Osmoregulation in 
Teleost fish. Am. Zool. 41: 781794.

Montserrat, N., N.J.C. Gabillard, E. Capilla, M.I. Navarro, J. Gutiérrez. 2007. Role of insulin, insulin-like growth factors, and muscle regulatory factors in the compensatory growth of the trout (Oncorhynchus mykiss). General and Comparative Endocrinology. 150: 462-472.

Moriyama, S., Ayson, G., Kawauchi, H., 2000. Growth regulation by insulin-like growth factor-I in fish. Biosci. Biotechnol. Biochem. 64: 1553-1562.

Mulyati, S., M. Zairin Jr., dan M.M. Raswin. 2002. Pengaruh Umur Larva Saat Dimulainya Perendaman dalam Hormon Tiroksin terhadap Perkembangan, Pertumbuhan, dan Kelangsungan Hidup Ikan Gurami (Osphronemus gouramy) Effect of Thyroxine on Development, Growth and Survival of Giant Gouramy (Osphronemus gouramy) Larvae. JurnalAkuakultur Indonesia . 1(1): 21-25.

Peterson, B.C., Waldbieser, G.C., Bilodeau, A.L., 2005. Effects of recombinant bovine somatotropin on growth and abundance of mRNA for IGF-I and IGF-II in channel catfish (Ictalurus punctatus). J. Anim. Sci. 83: 816824.

Peterson, BC., AL. Bilodeau-Bourgeois, and, BC. Small. 2009. Small Response of the somatotropic axis to alterations in feed intake of channel catfish (Ictalurus punctatus). Comparative Biochemistry and Physiology, Part A 153: 457-463.
Plisetskaya, E.M., S.J. Duguay, and C. Duan. 1994. Insulin and InsulinLike Growth Factor in Salmonids. Comparison of Structure, Expression and Regulation. In: K.G. Davey, R.E. Peter and S.S. Tobe (Eds.), Perspectives in Comparative Endocrinology, National Research Council, Ottawa. pp. 226-233.

Poppinga, J., J. Kittilson, S.D.. McCormick, M.A. Sheridan. 2007. Effects of Somatostatin on The Growth Hormone - Insulin-Like Growth Factor Axis and Seawater Adaptation of Rainbow Trout (Oncorhynchus mykiss). Aquaculture. 273: 312-319.

Pozios, K.C., J. Ding, B. Degger, Z. Upton, and C. Duan. 2001. IGFs Stimulate Zebrafish Cell Proliferation by Activating MAP Kinase and PI3-Kinase-Signaling Pathways. Am. J. Physiol. Regul. Integr. Comp. Physiol. 280: R1230-R1239.

Pusat Data Statistik dan Informasi Kementerian Kelautan dan Perikanan (KKP). 2015. Statistik Perikanan Tangkap, Perikanan Budidaya dan Ekspor - Import Setiap Provinsi Seluruh Indonesia. 2003-2010.

Reinecke, M. 2010. Review Paper: Influences of The Environment on The Endocrine and Paracrine Fish Growth Hormone - Insulin-Like Growth Factor-I System. Journal of Fish Biology. 76: 1233-1254.

Rodgers, B.D., Roalson, E.H., Thompson, C., 2008. Phylogenetic analysis of the insulin-like growth factor binding protein (IGFBP) and IGFBP-related gene families. Gen. Comp. Endocrinol. 155: 201-207. 
Sakdiah, M., M. Zairin Jr., dan O. Carman. 2003. Pengaruh Lama Perendaman di Dalam Larutan Hormon Triiodotironin (T3) terhadap Perkembangan, Pertumbuhan dan Kelangsungan Hidup Larva Ikan Gurame (Osphronemus gouramy Lac.) Effect of Exposure Time of Triiodothyronine (T3) Hormone Solution on Development, Growth and Survival Rate of Giant Gouramy (Osphronemus gouramy Lac.). JurnalAkuakultur Indonesia. 2(1): 1-6.

Suprayudi, M.A. dan M. Setiawati. 2003. Kebutuhan Ikan Gurame (Osphronemus gouramy Lac.) Akan Mineral Fosfor. Dietary Phosphorus Requirement of Giant Gouramy (Osphronemus gouramy Lac.). JurnalAkuakultur Indonesia. 2(2): 67-71.

Vong, Q.P., Chan, K.M., Cheng, C.H.K.,
2003. Quantification of common carp (Cyprinus carpio) IGF-I and IGF-II mRNA by real-time PCR: differential regulation of expression by GH. J. Endocrinol. 178: 513-521.

Weber, G., Sullivan, C.V., 2000. Effects of Insulin-Like Growth Factor-I on In Vitro Wnal Oocyte Maturation and Ovarian Steroidogenesis in Striped Bass, Morone saxatilis. Biol. Reprod. 63: 1049-1057.

Yan, B., Zhu C.D., Guo J.T., Zhao, L.H., and Zhao, J.L. 2012. miR-206 Regulates The Growth of The Teleost Tilapia (Oreochromis niloticus) Through The Modulation of IGF-1 Gene Expression. J. Exp Biol 216:12651269.

Zonneveld N, E. A. Huisman dan J.H. Boon. 1991. Prinsip-Prinsip Budidaya Ikan. PT Gramedia Pustaka Utama. Jakarta. $318 \mathrm{hlm}$. 